\title{
LA LEY ORGÁNICA DE MEJORA DE LA CALIDAD EDUCATIVA (LOMCE) DE 2013: ¿UNA REFORMA MÁS?
}

\author{
The Law for the Improvement of the Education Quality (LOMCE) \\ of 2013: one more reform?
}

\author{
Antonio Viñao* \\ Fecha de recepción: 12/06/2015 • Fecha de aceptación: 26/09/2015
}

Resumen: El 9 de diciembre de 2013 fue aprobada la Ley Orgánica para la Mejora de la Calidad Educativa (LOMCE) actualmente en fase de desarrollo y aplicación. En este artículo se exponen sus orígenes inmediatos - el fallido pacto por la educación promovido por el ministerio Gabilondo del Partido Socialista en los años 2009-2010- Después se analizan la inserción de la LOMCE en la política social y económica del Partido Popular, y en la política educativa propugnada desde dicho partido o llevada a cabo en las Comunidades Autónomas gobernadas por el mismo, así como los objetivos de la nueva reforma a corto, medio y largo plazo. En este análisis se destacan los rasgos o aspectos de índole neoconservadora apreciables en la nueva reforma, y se incluyen algunas referencias a su proceso de aplicación.

Palabras clave: LOMCE. Política educativa. Neoconservadurismo. Partido Popular.

Abstract: The Organic Law for the Improvement of the Education Quality (Ley Orgánica para la Mejora de la Calidad Educativa, LOMCE), currently under development and implementation, was passed on December 9, 2013. In this paper we examine its immediate origins, i.e., the failed education agreement promoted by the Socialist Party's minister Gabilondo in the years 2009-2010. We then tackle the insertion of the LOMCE in the Popular Party's social and economic policy as well as in the education policy defended by this party and carried out in the Autonomous Communities it governs. Finally, we analyze the short, middle and long term goals of the new reform. This analysis emphasizes the neoconservative features of the new reform and includes some references to its implementation process.

Keywords: LOMCE. Education policy. Neoconservatism. Popular Party.

\footnotetext{
* Universidad de Murcia. Facultad de Educación. Dpto. de Teoría e Historia de la Educación. Campus universitario de Espinardo. 30100 Murcia. avinao@um.es.
} 


\section{INTRODUCCIÓN}

El 10 de diciembre de 2013 se publicó en el Boletín Oficial del Estado la Ley Orgánica 8/2013, de 9 de diciembre, para la mejora de la calidad educativa que, según uno de sus analistas y defensores, "podemos considerar como la primera ley que trata de desarrollar el artículo 27 de la Constitución desde una óptica de centro derecha». No olvida, quien lo afirma, ni el Estatuto de Centros Escolares (LOECE) de 1980, promovido por un gobierno de la Unión de Centro Democrático (UCD), ni la Ley Orgánica de Calidad de la Educación (LOECE) de 2002, promulgada bajo un gobierno del Partido Popular. Simplemente, considera que ninguna de las dos llegó a ser aplicada. La primera ley, porque fue «recurrida por el Partido Socialista ante el Tribunal Constitucional que le dio la razón en muchas de sus objeciones», sin que los acontecimientos posteriores de 1981 permitieran «una adecuación de la ley a la sentencia». La segunda, porque la llegada del Partido Socialista al poder trajo consigo la paralización de su «calendario de aplicación» en mayo de $2004 .{ }^{1}$

Las frases y afirmaciones anteriores están escritas para sostener seguidamente, como conclusión, que tras la Constitución de 1978 «la orientación de la política educativa» en nuestro país, «y el mismo sistema educativo son obra de gobiernos de izquierda, con el apoyo de los nacionalistas» por supuesto de los periféricos, no del nacionalismo español - ${ }^{2}$ La LOMCE vendría a cambiar, así pues, dicha doble orientación izquierdista y nacionalista-periférica.

Dejo a un lado, en este momento, la discutible y superficial interpretación que se hace de la política educativa en España tras la Constitución de 1978. Si me refiero a ella es porque, al menos en su inicio, el texto sitúa la LOMCE en un contexto temporal más amplio. Entre otras razones, porque este es uno de los enfoques que necesariamente debe adoptar eso que se ha dado en llamar la «historia del presente»o de lo inmediato - no confundir con la historia que nos abre los ojos sobre el presente-.${ }^{3}$ Sobre todo cuan-

\footnotetext{
${ }^{1}$ José Luis Sastre Álvaro, «El proceso de elaboración de la LOMCE. Consideraciones generales», en Claves de la reforma educativa. A propósito de la nueva Ley Orgánica para la mejora de la calidad educativa, coord. Carmen Fernández Rodríguez (Madrid: Constitución y Leyes, 2015), 11-55 (citas y referencias en 11-12). El autor es, en el momento de redactar estas líneas, Senador por Ceuta del Partido Popular. Y el artículo una síntesis expositiva —y sobre todo justificativa—, de la LOMCE desde una posición favorable a la misma.

2 Sastre Álvaro, «El proceso de elaboración de la LOMCE», 12.

${ }^{3}$ François Bédarida, «Definición, método y práctica de la Historia del Tiempo Presente», Cuadernos de Historia Contemporánea, 20 (1998): 19-27.
} 
do, como sucede en este caso, las consecuencias de ese presente que se analiza - la LOMCE — no son las de un pasado próximo, aunque ya tenga su historia, sino que están aflorando día tras día, cuando esto se escribe, en el proceso de aplicación de la misma.

La LOMCE no es todavía un pasado próximo, pero es previsible que lo sea si se tiene en cuenta:

- Que fue aprobada con solo los votos del partido que la promovía, la abstención de la Unión del Pueblo Navarro y el voto en contra del resto de los partidos políticos.

- Que todos los demás partidos políticos, excepto Foro Asturias, Unión del Pueblo Navarro y Unión, Progreso y Democracia, suscribieron el 17 de julio de 2013, en pleno debate parlamentario del proyecto de ley, el compromiso escrito de derogarla en cuanto una nueva mayoría parlamentaria lo permitiera. ${ }^{4}$

- Que la reciente emergencia en el escenario político del país de nuevos partidos como Podemos o Ciudadanos, no hace suponer un destino diferente a dicha ley.

¿Qué sentido tiene, pues, analizar históricamente el presente de una reforma educativa más, en plena fase de aplicación, cuando es muy posible que dicha fase sea paralizada, como ya sucedió con la LOECE en 1980, y que la ley sea modificada en cuanto el partido que la promovió pierda la mayoría absoluta en las próximas elecciones? ¿No será esta una ley más a la que vendrá a sustituir otra que, a su vez, será sustituida por otra, etc., etc.,...? En este sentido, no parece que valga la pena dedicarle mucha atención. Será una ley, una reforma más, a la que sucederán otras. Más vale plantearse qué sucederá o qué hacer una vez que se paralice su aplicación, se modifique o se derogue. ${ }^{5}$ Sin embargo, la LOMCE, por un lado, posee un relevante valor testimonial e histórico en relación con la política educativa del partido conservador español. En este sentido, no es una reforma más: refleja, mejor que

\footnotetext{
${ }^{4}$ URL: http://www.europapress.es/sociedad/noticia-grupos-oposicion-comprometen-escrito-derogar-lomce-20130717152221.html. Consulta efectuada el 21 de mayo de 2015.

${ }^{5}$ Esta es la posición o enfoque que mantuve en un breve texto, escrito por encargo, publicado en un número monográfico sobre la LOMCE de la revista de la Confederación Española de Asociaciones de Padres y Madres de Alumnos (CEAPA): «La LOMCE: un presente conocido, un futuro incierto», Padres y Madres de Alumnos y Alumnas, 117 (2014): 22-24. La perspectiva del trabajo que ahora se publica es otra, pero no se opone a la del breve texto mencionado. Al contrario, ambos se complementan.
} 
la LOCE de 2002, el modelo educativo de dicho partido aunque, como se verá, todavía haya quienes, desde posiciones próximas o que se identifican con el mismo, les parezca insuficiente o de corto alcance. Por otro, los cambios que introduce solo se entienden dentro de dichos modelo y política. Es previsible que sea una reforma más desde un punto de vista temporal, pero no una reforma intranscendente o poco significativa desde el punto de vista ideológico y político. Viene a validar y sustentar legalmente determinadas medidas políticas adoptadas en las Comunidades Autónomas regidas por el Partido Popular, así como, en parte, por otros partidos conservadores de ámbitos territoriales autonómicos. En síntesis, constituye un paso más hacia una determinada configuración del sistema educativo español acorde con el mencionado modelo y con dichas políticas. Su análisis se justifica en razón del mismo interés que suscita, por buscar un símil histórico, el de la Ley de Instrucción Primaria de 2 de junio de 1868, de Severo Catalina, y su Reglamento de 10 del mismo mes y año, derogados pocos meses después, tras la revolución de septiembre, por un Decreto-ley de 14 de octubre. Es cierto que solo estuvo vigente durante cuatro meses, tres de ellos de pleno verano, pero es la disposición legal que mejor refleja el pensamiento y la política educativa del entonces llamado partido neocatólico. De igual modo, la LOMCE es la disposición legal que mejor ejemplifica, por el momento, el pensamiento y política educativa del partido conservador español y de nuestros actuales neoconservadores, así como sus propósitos, estrategias y prácticas. El objetivo de este texto no es, pues, el de exponer el contenido de la LOMCE de un modo sistemático, o el de llevar a cabo un análisis jurídico de la misma, sino el de situarla en el contexto más amplio, para su mejor comprensión, de dichos pensamiento y política. ${ }^{6}$

Con tal fin, primero me referiré a sus orígenes inmediatos —el fallido pacto por la educación promovido por el ministerio Gabilondo del Partido Socialista en los años 2009-2010-. Después analizaré la inserción de la

\footnotetext{
${ }^{6}$ Aunque en este texto utilice aspectos ya tratados en los trabajos que seguidamente refiero, remito, en relación con la política educativa del Partido Popular y su modelo de sistema educativo a lo dicho en «Neoliberalismo a la española. Límites, contradicciones y realidades», Cuadernos de Pedagogía, 270 (1998): 75-80, «El concepto neoliberal de calidad de la enseñanza: su aplicación en España (1996-1999)», Tempora. Revista de Historia y de Sociología de la Educación, 4 (2001): 63-87, «El desmantelamiento del derecho a la educación: discursos y estrategias neoconservadoras», Áreas. Revista Internacional de Ciencias Sociales, 31 (2012): 97-107, y «El modelo neoconservador de gobernanza escolar: principios, estrategias y consecuencias en España», en Gobernanza escolar democrática, coords. Jordi Collet y Antoni Tort (Madrid: Morata, en prensa). Este trabajo ha de ser visto como complemento de los anteriores. De ahí que, en ocasiones, se repitan argumentos, ideas o aspectos que ya figuran en ellos.
} 
LOMCE en la política social y económica del Partido Popular y en la política educativa propugnada desde este partido, o llevada a cabo en las Comunidades Autónomas gobernadas por el mismo, así como los objetivos de la nueva reforma a corto, medio y largo plazo. En este análisis se destacan los rasgos o aspectos de índole neoconservadora apreciables en la nueva reforma, y se incluyen algunas referencias a su proceso de aplicación.

\section{LOS ORÍGENES INMEDIATOS: UN NUEVO Y FALLIDO PACTO POR LA EDUCACIÓN (2009-2010)}

Desde la aprobación de la Constitución de 1978 se han promulgado en España, por ley orgánica, una decena de reformas educativas. Si a ellas se añaden los intentos y proyectos de reforma — por ejemplo, el fracasado proyecto de reforma de la Humanidades del ministerio Aguirre en 1998- y las reformas experimentales — por ejemplo, la de las enseñanzas medias del ministerio Maravall entre los años 1983 y 1987- dicho número supera la decena. Cada cambio en el partido que gobierna, o incluso con el mismo partido, ha supuesto una nueva reforma educativa o un proyecto de reforma. La opinión pública parece demandar, de modo casi generalizado, un pacto en educación -a nuestro juicio inviable por el momento— que acabe con esta situación.

Corresponde a otros trabajos de este número, en su parte monográfica, el análisis de los fracasados intentos de llegar a un acuerdo o pacto en educación durante las dos últimas décadas. ${ }^{7}$ En este caso, para situar la LOM$\mathrm{CE}$ en un contexto más amplio, debemos hacer referencia al último de ellos, el promovido por el Partido Socialista, a través del ministro Gabilondo. ${ }^{8}$ En el proceso de negociación, ambos partidos, el Popular y el Socialista dejaron constancia escrita de sus propuestas. El primero, el 18 de enero de 2010, en un documento titulado Propuestas del PP para un pacto por la reforma $y$ mejora de la educación en España. ${ }^{9}$ El segundo, nueve días después, en otro

\footnotetext{
${ }^{7}$ Remito a las páginas de los artículos de Manuel de Puelles y Alejandro Tiana publicados en este mismo número, en las que tratan esta cuestión en relación con los fallidos intentos de un pacto en educación de 1997, 2005 y 2009-2010.

8 Puede afirmarse que el objetivo político principal del ministerio Gabilondo, y el que, para alcanzarlo, se eligiera como ministro a una persona de sus características, sería el de conseguir un pacto por la educación con el Partido Popular.

9 Partido Popular, Propuestas del PP para un pacto por la reforma y mejora de la educación en España (Madrid, 18 de enero de 2010). Accesible en http://www.pp.es/sites/default/files/documentos/1906-20100118171348.pdf. Consulta efectuada el 20 de mayo de 2015.
} 
documento con el título de Propuestas para un pacto social y político por la educación..$^{10}$ El final es conocido: no hubo acuerdo y el Partido Popular, con fecha de 20 de mayo de dicho año, emitió un nuevo documento en el que definía su posición al respecto cuando ya las encuestas anunciaban su previsible triunfo por mayoría absoluta en las próximas elecciones generales ${ }^{11}$. Los dos objetivos principales del pacto - «emprender las reformas que nos permitan combatir con eficacia el fracaso escolar» y «elevar la calidad de la educación»—, se decía desde dicho partido, no se podían «alcanzar con meros retoques del modelo educativo vigente en España desde hace más de veinte años». Lo que se necesitaba era «una reforma en profundidad del sistema», un nuevo modelo que respondiera, entre otros aspectos, a los principios de recentralización - apoyo al castellano como «lengua vehicular en la enseñanza», garantía y reforzamiento de unas «enseñanzas comunes impartidas en los mismos términos en toda España», establecimiento de un «verdadero sistema nacional de evaluación y rendición de cuentas» con el que informar a las familias, y «mantenimiento de los cuerpos nacionales del profesorado» con el fin de garantizar su «movilidad en todo el territorio nacional»-, y libertad de elección por los padres «del tipo de educación y centro educativo que quieren para sus hijos». ${ }^{12}$

La oportunidad de dar forma legal a ese nuevo modelo llegaría con el triunfo por mayoría absoluta del Partido Popular en las elecciones de noviembre de 2011. Su materialización sería, o debía ser, la LOMCE.

\section{LA LOMCE EN EL MARCO DE LA POLÍTICA GENERAL —SOCIAL Y ECONÓMICA - Y EDUCATIVA DEL PARTIDO POPULAR}

La LOMCE constituye una pieza más, relevante, pero una más de una política educativa determinada, no siempre coherente ni sistemática, construida en ocasiones sobre la marcha, que, a su vez, se integra en un pro-

\footnotetext{
${ }^{10}$ Ministerio de Educación, Propuestas para un pacto social y político por la educación (Madrid, 27 de enero de 2010). Accesible en http://www.mecd.gob.es/dctm/ministerio/horizontales/prensa/documentos/2010/conferencia-sectorial-propuesta-pacto.pdf?documentId=0901e72b800adfb5. Consulta efectuada el 20 de mayo de 2015.

${ }^{11}$ Partido Popular. Oficina de Información, Posición del Partido Popular en relación al pacto sobre la reforma del modelo educativo (Madrid, 6 de mayo de 2010). Accesible en http://www.elpais.com/elpaismedia/ ultimahora/media/201005/06/sociedad/20100506elpepusoc_1_Pes_PDF.pdf (consulta efectuada el 20 de mayo de 2015).

12 Partido Popular, Posición del Partido Popular, 2-6.
} 
grama o ideario político más amplio, el del tradicional conservadurismo autoritario español remozado y adaptado a los nuevos tiempos. ${ }^{13}$ Detrás de dicho programa hay, por supuesto, toda una filosofía social o modelo de organización social de rasgos profundamente desigualitarios. El objetivo general, en síntesis, es el desmantelamiento del llamado Estado social o del bienestar, producto —más teórico que real en el caso español— ${ }^{14} \mathrm{de}$ un pacto social y constitucional basado, como remedio o antídoto frente a las propuestas revolucionarias, en un sistema fiscal de impuestos progresivos y el peso relevante de los gastos sociales (sanidad, pensiones, seguro de desempleo, asistencia social, educación, etc.) en los presupuestos públicos.

Una de las piezas clave de ese Estado social es, o era, la educación entendida como un espacio público — que pertenece al ámbito de lo público o común del que son responsables los poderes públicos- ${ }^{15}$ sustraído a su mercantilización, financiado fundamentalmente con impuestos y configurado para garantizar el derecho a la educación como derecho social: derecho a una educación básica de cierta calidad desde el nacimiento hasta al menos los 16 o 18 años, así como a una formación profesional; derecho, por quienes carecen de medios, a la percepción de becas y ayudas al estudio en la enseñanza post-obligatoria; y programas específicos de educación compensatoria y de refuerzo y ayuda para quienes las precisen, ya se trate de centros docentes, alumnado, familias o zonas y áreas de pobreza. Si la educación no puede hacer mucho, por sí sola, para amortiguar las diferencias sociales que, al menos, no las refuerce. ${ }^{16}$

\footnotetext{
${ }^{13}$ Sobre el particular, remito a lo dicho en «El modelo neoconservador de gobernanza escolar: principios, estrategias y consecuencias en España».

${ }^{14}$ En relación con las debilidades e insuficiencias del Estado del bienestar en España, véase Vicenç Navarro López, Bienestar insuficiente, democracia incompleta. Sobre lo que no se habla en nuestro país (Barcelona: Anagrama, 2002), y Vicenç Navarro López (coord.), El estado del bienestar en España (Madrid: Tecnos, 2004).

15 Suele emplearse en España el adjetivo «público» para referirse al sector educativo de titularidad pública. Dada la polisemia del término y los malentendidos que origina - Antonio Viñao, «Público-privado. Concepciones, malentendidos, estrategias», Cuadernos de Pedagogía, 409 (2011): 80-83, y «Escuela pública-privada», Cuadernos de Pedagogía, 451 (2014): 24-27, número monográfico sobre «40 años de educación. 40 años de Cuadernos»—, sugiero su sustitución por el adjetivo "común» en el sentido no ya de la common school estadounidense, sino de bien o espacio común de acuerdo con la caracterización de dicha expresión efectuada por Elinor Ostrom, Governing the Commons: The Evolution of Institutions for Collective Action (Cambridge: Cambridge University Press, 1990). Traducción al castellano: El gobierno de los bienes comunes: la evolución de las instituciones de acción colectiva (México D. F.: Fondo de Cultura Económica, 2000).

${ }^{16}$ La caracterización que se hace del derecho a la educación es la que corresponde a la perspectiva socialdemócrata del Estado social o del bienestar. Existen, como se verá, otras concepciones del mis-
} 
Por supuesto, el desmantelamiento del Estado del bienestar y, con él, del derecho a la educación implica una ruptura del pacto socialdemócrata y una «revuelta fiscal»: reducción de impuestos y establecimiento de transferencias y exenciones a los que más tienen para que, teóricamente, creen riqueza y empleo y, al mismo tiempo, reducción de los gastos sociales - los popularmente llamados «recortes»- y apertura al capital privado de todo lo hasta entonces público o común que pueda ser privatizado. Es decir, todo lo público y común, hasta el Estado.

Los principios o ideario básico de dicha política educativa, aquella en la que hay que enmarcar la LOMCE para su comprensión, son los siguientes: ${ }^{17}$

- El paso del papel o función de los poderes públicos como responsables del suministro y calidad de la educación al de simples instrumentos de regulación y evaluación de un mercado educativo, promovido por y desde esos mismos poderes, sin responsabilidad alguna por el suministro y calidad de dicho servicio. Dicha responsabilidad se transfiere a los centros docentes — dirección y profesorado-, los padres y madres y al alumnado, es decir, a personas individuales o a las instituciones docentes, o, de un modo más vago, a la sociedad en su conjunto $\mathrm{y}$, a título individual, a quienes la componen.

- La libertad de enseñanza entendida, de modo restrictivo, como: a) libertad de creación de centros docentes y establecimiento de un ideario determinado en el caso de que se trate de un centro privado (los centros públicos deben ser ideológicamente neutrales y, por tanto, carecer de ideario; en todo caso, su ideario es la neutralidad); ${ }^{18}$ b) libertad de las familias para elegir el centro que se adecúe a sus convicciones reli-

\footnotetext{
mo diferentes e incluso contrapuestas a ella. Desde una perspectiva jurídica internacional, sobre todo europea, véase el libro de Pablo Meix Cereceda, El derecho a la educación en el sistema internacional y europeo (Valencia: Tirant lo Blanch, 2014) objeto de reseña en este mismo número de Historia y Memoria de la Educación.

${ }^{17}$ En la definición de esta política ha jugado, y juega, un papel fundamental la Fundación para el Análisis y los Estudios Sociales (FAES) presidida por José M. ${ }^{a}$ Aznar. Sobre el particular, véase Antonio Olmedo \& Eduardo Santa Cruz Grau, «Neoliberalism, policy advocacy and think tanks in the Spanish educational arena: The case of FAES», Education Inquiry, 4 (3), (2013): 473-496, y Geo Saura, «Think tanks y educación. Neoliberalismo de FAES en la LOMCE», Archivos Analíticos de Políticas Educativas, 23 (106), (2015): http://dx.doi.org/10.14507/epaa.v23.106

18 Por lo general, y salvo que se diga otra cosa, cuando me refiero a centros docentes públicos o privados, o al sector o red pública o privada, la distinción se basa en la titularidad de los mismos. Se trata de un criterio jurídico, no económico, prestacional o ideológico.
} 
giosas, morales o pedagógicas; y c) libertad de los centros para elegir los materiales de enseñanza e impartir asignaturas no previstas en el currículo oficial, así como para elegir al alumnado. En resumen, una opción favorable al pluralismo intercentros, rechazo del pluralismo intracentros y negación u olvido de la libertad de cátedra, académica o científica del profesor, así como de la libertad de conciencia del alumnado: una concepción instrumental de la libertad de enseñanza cuyo fundamento o base no es tanto dicha libertad, en sí misma considerada, sino el modo de llevar a la práctica el derecho/libertad de los padres para elegir para sus hijos un centro docente en función de sus convicciones religiosas, morales o pedagógicas. Este derecho/libertad pasa a ser el fundamento y origen de la libertad de enseñanza, no al contrario. Esta última es consecuencia de la anterior, ya que, para sus defensores, es solo la existencia de ese derecho/libertad de los padres lo que garantiza que haya libertad de enseñanza. ${ }^{19}$

- La consideración de lo público como algo en sí mismo ineficiente, improductivo y costoso, por no decir enfermo, ${ }^{20}$ frente a lo privado como algo por sí mismo eficiente y barato para todos, con la consiguiente aversión tanto hacia la figura del funcionario como hacia la del asalariado estable y con unos derechos laborales garantizados. Preferencia general por la figura del trabajador autónomo o profesional —ahora llamado emprendedor-, solo responsable ante sí mismo, que se contrata en función de las necesidades — es decir, con carácter temporal— y por servicios o trabajos concretos, que se paga su seguridad social y tiene, si puede, su plan privado de pensiones.

- La consecución de la mejora de la calidad en la enseñanza mediante la implantación de mecanismos de competencia mercantiles —un mercado o cuasi-mercado educativo-, la diversificación de la oferta educativa con el fin de favorecer la existencia de centros docentes llamados «de excelencia», el establecimiento de evaluaciones con test estandarizados, la difusión pública de sus resultados y la rendición

\footnotetext{
${ }_{19}$ M. ${ }^{a}$ Dolores Ferré Fernández, «El derecho de los padres a elegir la educación de sus hijos en España», en Sistema educativo y libertad de conciencia, coord. Santiago Catalá (Madrid: Alderabán, 2009), 61-71.

${ }^{20}$ Sobre «la enfermedad de lo público», véase Francisco López Rupérez, La gestión de calidad en educación (Madrid: La Muralla, 1994), 12. Es curioso que muchos de los detractores de lo público sean funcionarios, o que todos ellos estén dispuestos a ocupar cargos en el sector público a poco que se les proponga. Parece como si dicha «enfermedad» no les afectara o que desapareciera cuando ocupan cargos públicos.
} 
de cuentas por los centros docentes y profesores en función de los mismos. $^{21}$

- La consideración de los centros públicos como entes teóricamente autónomos a los que se les aplican técnicas de gestión propias del sector privado, así como de la red pública como subsidiaria de la privada.

- La configuración de ese mercado educativo requiere implantar la libre elección de centro docente por las familias —o sea, la libre selección del alumnado por aquellos centros docentes en los que la demanda supera a la oferta- lo que implica el llamado «distrito único», una amplia oferta de centros concertados y, como solución ideal o definitiva, los cheques o bonos por el importe del puesto escolar y/o las desgravaciones fiscales por dicho importe para quienes opten por centros privados de pago.

- La creencia de que la calidad de la enseñanza no guarda relación con el gasto por alumno, en especial el gasto público, ni con el número de alumnos por profesor o aula, sino con una mejor gestión de los recursos. En otras palabras, que es posible una mejora en la calidad con un menor gasto, en especial público, en educación.

Si tuviera que sintetizar dicha política en el caso español, la resumiría en una breve frase: favorecer a la enseñanza privada y a las empresas suministradoras de servicios o material educativo de cualquier índole. ${ }^{22} \mathrm{~A}$ ello

${ }^{21}$ En relación con el proceso de configuración de un mercado educativo en España, véase Antonio Olmedo, «De la participación democrática a la elección de centro: las bases del cuasimercado en la legislación educativa española», Archivos Analíticos de Políticas Educativas, 16 (21), (2008): 1-32, y «Policy-makers, market and advocates and edu-businesses: new and renewed players in the Spanish education policy arena», Journal of Education Policy, 28 (1), (2013): 55-76. Sobre la aplicación de la política del llamado New Public Management (NPM), tan relacionada con la configuración de mercados educativos, en la red pública de centros docentes, adaptándola al contexto y características del sistema educativo español y en relación con Cataluña y el Partido de los Socialistas de Cataluña, véase Antoni Verger y Marta Curran, "New public management as a global education policy: its adoption and re-contextualization in a Southern European setting», Critical Studies in Education, 55 (3), 2014, 253-271.

${ }^{22}$ En una reciente crítica periodística de la política llevada a cabo por la titular de la Consejería de Educación de la Comunidad valenciana (José Ramón Giner, «Cuestión de grados», El Pais. Comunidad valenciana (8 de septiembre de 2014), 20), el autor decía que en todo el "popurrí» de decisiones adoptadas — «tarteras, jornada única, clases de 45 minutos, pizarras digitales y bilingüismos»— no era posible detectar una línea política clara salvo la de «beneficiar a la enseñanza privada», algo que, a su juicio, «no constituye, por sí mismo, una política educativa» ya que «una política que merezca ese nombre requiere unos objetivos, un fin, unos planes a largo plazo» que no se aprecian en la actuación «llena de improvisaciones» de la consejera. Craso error. Esa política tiene un objetivo y un plan a largo plazo perfectamente trazados: favorecer a la enseñanza privada y, dentro de ella, a la confesional católica y a determinados grupos o personas ideológica y económicamente afines. 
añadiría que no a toda la enseñanza o actividad privada, sino a una parte de ella —la ideológica y/o económicamente afín- más que a otras. Desde posiciones supuestamente liberales, lo que se pide es, como no podía ser de otro modo, libertad, pero unas libertades y no otras: «libertad de elección de centro [financiando a las familias mediante bonos y/o desgravaciones fiscales], libertad para crear centros por iniciativa de las familias, libertad para cuestionar el currículum [oficial], libertad para escribir y elegir los libros de texto, libertad para exigir disciplina y urbanidad, libertad para que los centros entren en sana competencia por la excelencia» pues «en estos momentos [2009], no existe libertad real de los padres [en España] para elegir el centro que más se adecúe a sus convicciones morales, filosóficas o pedagógicas». ${ }^{23}$ La inexistencia de dicha libertad es la que exigía una nueva ley que la garantizara. Esta ley tendría que ser la LOMCE. Lo que sucede, es que al igual que la política educativa del ministerio Aguirre (1996-1999) en relación con la elección de centro fue calificada en su día de «tímida» por Pedro Schwartz, un economista y destacado ideólogo en España del neoliberalismo conservador, ${ }^{24}$ recientemente, desde el ámbito jurídico-político, otra destacada defensora de tales principios, no duda en afirmar que la LOMCE de 2013 es una disposición de "corto alcance», "ambigua» en relación con los conciertos educativos y «bastante corta en su planteamiento reformista, al menos desde la perspectiva jurídica del reconocimiento de los derechos y libertades de los principales protagonistas [léase padres y titulares de centros privados] de la actividad de enseñanza», por no reconocer el libre derecho de los centros concertados a seleccionar su alumnado y condicionar los conciertos al cumplimiento de determinadas exigencias. ${ }^{25}$

\footnotetext{
${ }^{23}$ Victoria Llopis, «Libertad, calidad y educación: análisis de la situación en España y comparativa con Europa», en Sistema educativo y libertad de conciencia, 73-85 (citas en pp. 85 y 73).

${ }^{24}$ Pedro Schwartz, "Tímida ministra», El País (21 de junio de 1997), 46. Como contraste léase, del mismo autor, «Esperanza Aguirre, modelo de gobernantes liberales», ABC (18 de septiembre de 2013), 3, donde, además de aclarar el por qué del odio de los pedagogos «progres» a la ex-ministra de Educación, la califica de «paradigma» de la «corriente» que «cree en el esfuerzo y la ambición personal junto con el acicate de la libre competencia» frente a otra corriente, también liberal, que «combina la indulgencia personal con el paternalismo social».

${ }^{25}$ Isabel María de los Mozos y Touya, «La Ley Orgánica para la Mejora de la Calidad Educativa: una reforma contestada, pero de corto alcance», Revista Española de Pedagogía, 257 (2014): 23-38 (citas y referencias en pp. 23, 28-29 y 33-34).
} 


\section{OBJETIVOS A CORTO, MEDIO Y LARGO PLAZO}

El modo de elaboración y presentación de la reforma que daría lugar a la LOMCE es un claro ejemplo de chapuza técnica. La primera información oficial sobre el planteamiento de lo que se pretendía, tuvo lugar 9 de julio de 2012 mediante la inclusión en el portal de internet del Ministerio de un documento de "propuestas» que desapareció a los pocos días para ser sustituido por otro de título y contenido similar en formato "power point» y elaborado, por tanto, con un estilo esquemático. Ambos documentos, hoy no consultables salvo por quien guardara copia de los mismos, adolecían de baja calidad, carecían de coherencia interna, incluso expositiva, estaban llenos de lugares comunes y parecían más bien propios de un alumno universitario no muy cualificado. Quizás por ello desaparecieron con la misma presteza con que aparecieron. Nada más se supo de ellos, al igual que nadie parece saber quién los elaboró y de dónde partieron. Nada similar, como contraste, con el Libro Blanco que daría origen a la reforma de 1970, o los libros impresos que abrieron los debates de la Ley Orgánica General del Sistema Educativo (LOGSE) de 1990 y la Ley Orgánica de Educación (LOE) de 2006.

Por supuesto, nada se ha hecho público tampoco sobre el equipo o personas autoras del anteproyecto de ley. Lo que sí se sabe es que tuvo hasta cuatro versiones y dos preámbulos claramente contrapuestos: uno, el primero, acorde con sus planteamientos y objetivos reales, y otro más suave y "presentable», el que después figuraría en la ley, destinado a ocultarlos. Todo un prodigio de ingeniería discursiva en el que una buena parte del preámbulo, sobre todo sus párrafos iniciales, se contrapone a lo que después se dice en el texto legal. ${ }^{26}$ Por si ello no fuera suficiente, la técnica legislativa elegida - la de un articulado y disposiciones adicionales y finales

\footnotetext{
${ }^{26}$ Primer párrafo del preámbulo original: «La educación es el motor que promueve la competitividad de la economía y el nivel de prosperidad de un país. El nivel educativo es el que determina su capacidad de competir con éxito en la arena internacional [....], lo que representa una apuesta por el crecimiento económico y por conseguir ventajas competitivas en el mercado global».

Primer párrafo del segundo preámbulo, el aprobado y vigente: «Los alumnos son el centro y la razón de ser de la educación. El aprendizaje en la escuela debe ir dirigido a formar personas autónomas, críticas, con pensamiento propio. Todos los alumnos tienen un sueño, todas las personas jóvenes tienen talento. Nuestras personas y sus talentos son lo más valioso que tenemos como país».

Un buen análisis expositivo, y crítico, del proceso de elaboración y gestación de la LOMCE puede verse en Jaime Antonio Foces Gil, Política y administración de la educación en el Estado autonómico (1978-2014. Desigualdades regionales y cohesión del sistema educativo. Estudio de un caso singular: Castilla y León. Tesis doctoral, Departamento de Historia de la Educación y Educación Comparada, UNED (2015), 204-238.
} 
que van modificando o ampliando una ley anterior - resulta, para su consulta y comprensión, confusa. Todo hubiera quedado más claro con un texto refundido posterior en el que se hubiera indicado, de algún modo, lo que se modificaba o añadía.

Pese a la escasa transparencia y ocultamientos — por otra parte innecesarios-, a los continuos cambios que hubo en el equipo ministerial y en los responsables de sacar adelante el proyecto de ley, y a los eufemismos y aparente esquizofrenia que en ocasiones se aprecia entre lo que se dice y lo que se pretende y hace en el proceso de aplicación, la nueva ley tenía, y tiene, una serie de objetivos a corto, medio y largo plazo. Otra cosa es su consecución y correspondencia con los objetivos y principios declarados, así como la coherencia entre los mismos y entre ellos y el articulado de la ley. De ahí que no esté de más, transcribir lo que en el preámbulo de la LOMCE se dice al respecto con el fin de tenerlo en cuenta y confrontarlo con lo que seguidamente se dirá sobre los objetivos realmente perseguidos:

Los principales objetivos que persigue la reforma son reducir la tasa de abandono temprano de la educación, mejorar los resultados educativos de acuerdo con criterios internacionales, tanto en la tasa comparativa de alumnos y alumnas excelentes, como en la de titulados de Educación Secundaria Obligatoria, mejorar la empleabilidad, y estimular el espíritu emprendedor de los estudiantes. Los principios sobre los cuales pivota la reforma son, fundamentalmente, el aumento de la autonomía de los centros, el refuerzo de la capacidad de gestión de la dirección de los centros, las evaluaciones externas de fin de etapa, la racionalización de la oferta educativa y la flexibilización de las trayectorias.

A lo largo de este artículo abordaré estos objetivos y algún otro no hecho explícito. Excluyo dos. Primero, el de «reducir el abandono temprano de la educación» porque, además de depender de evolución del empleo y del paro, la LOMCE, sin decirlo de modo expreso, espera resolverlo mediante una operación de ingeniería estadística excluyendo del cómputo de abandonos a quienes se titulen en los programas de formación profesional básica. ${ }^{27}$ Segundo, el de «mejorar la empleabilidad», porque ello depende también,

${ }^{27}$ Juan Antonio Aunión, «Ingeniería estadística para reducir el abandono escolar», El País (15 de julio de 2013): 30. 
en buena parte, de mundo productivo-laboral, y por la estrecha relación que se establece en el preámbulo con el objetivo de "estimular el espíritu emprendedor de los estudiantes» sobre el que algo se dirá en este texto.

\section{Objetivos inmediatos o a corto plazo}

Desde un punto de vista estructural, la LOMCE tiene como objetivos el reforzamiento de la segmentación horizontal y vertical del sistema educativo; es decir, de la edad a partir de la cual finaliza la educación común o comprensiva y se accede a enseñanzas diferenciadas, y de la división del cursus académico en niveles, etapas, ciclos y cursos, así como del paso de uno a otro. ${ }^{28}$ En el primer caso, la solución adoptada por la LOMCE difiere de la mantenida por el Partido Popular en su programa electoral: ampliación a tres cursos del bachillerato a costa de la secundaria obligatoria y adelanto asimismo a los 15 años de la formación profesional de grado medio (figura n. ${ }^{\circ}$ ).

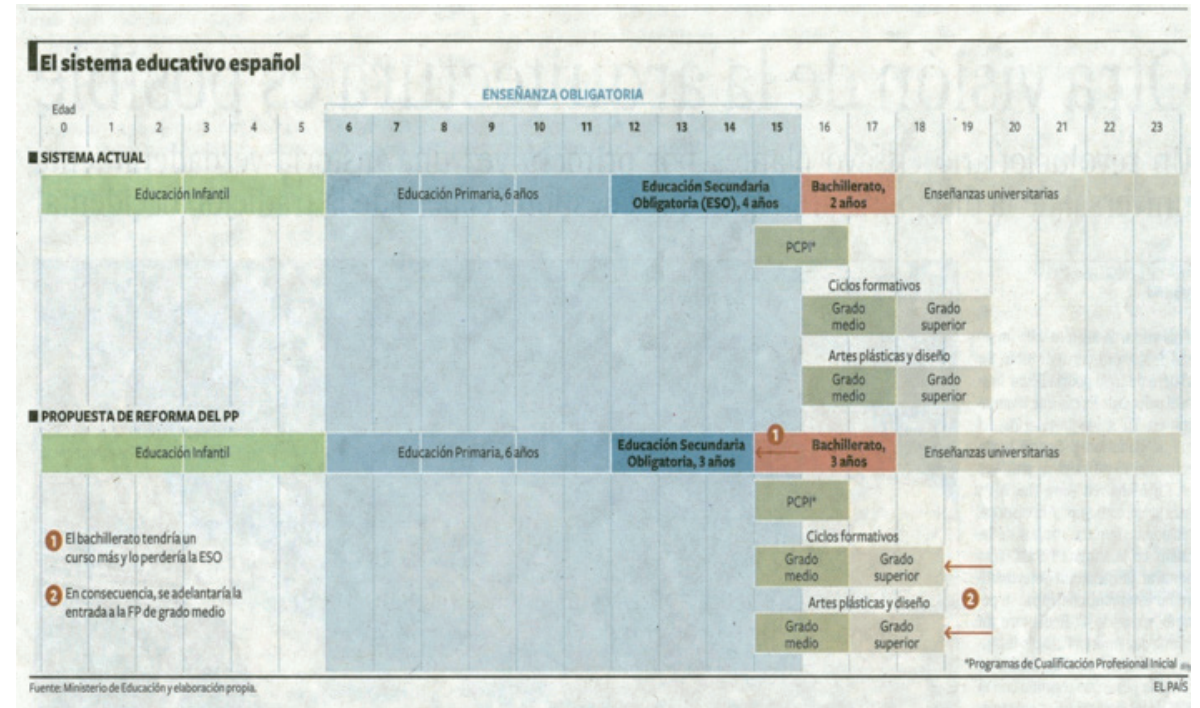

Figura 1. Estructura del sistema educativo español en la LOE y en la propuesta del Partido Popular.

${ }^{28}$ Sobre ambos conceptos, remito a lo dicho en Sistemas educativos, culturas escolares y reformas (Madrid: Morata, 2002), 50-51. 
En efecto, con «gran desilusión» por parte de la Asociación Nacional de Catedráticos de Instituto, ${ }^{29}$ y respetando formalmente la edad de comienzo del bachillerato y de finalización de la secundaria obligatoria — porque de este modo se obviaba la posibilidad de que los conciertos con la enseñanza privada se redujeran en un año-, la LOMCE opta, siguiendo la propuesta efectuada en este punto por Francisco López Rupérez en 2009 desde la FAES,$^{30}$ por (figura n. ${ }^{\circ} 2$ ):

- Diferenciar en el último curso de la secundaria obligatoria entre quienes optan por la rama «académica», que les llevará al bachillerato, y quienes lo hacen por la rama «aplicada», que les conducirá a la formación profesional.

- Establecer la posibilidad de acceder a una formación profesional básica desde el tercer curso de la secundaria obligatoria -14-15 años-o incluso desde el segundo curso - 13-14 años- si se repite curso.

- Introducir programas de mejora del aprendizaje y del rendimiento —necesariamente en aulas separadas-, en el segundo curso -12-13 años- de la secundaria obligatoria. Con ello se legaliza, refuerza y clarifica el objetivo de una práctica, la de la separación en función del rendimiento académico en aulas separadas, llevada a cabo en más de un centro de educación secundaria.

Por su parte, el reforzamiento de la segmentación vertical del sistema educativo - es decir, de su carácter selectivo o de filtro- se consigue mediante (figura n. ${ }^{\circ}$ ):

- La desaparición de los ciclos en la enseñanza primaria, ahora estructurada en una serie de seis cursos sucesivos.

- La repetición de curso en la secundaria obligatoria y el bachillerato cuando se tengan tres o más asignaturas suspensas, o solo dos en la secundaria obligatoria cuando se trata, de modo simultáneo, de Lengua Castellana y Literatura y Matemáticas.

\footnotetext{
${ }^{29}$ Felipe J. Vicente, «La gran desilusión», El País (9 de septiembre de 2012). URL: http://sociedad.elpais. com/sociedad/2012/09/07/actualidad/1347038640_401766.html. Consulta efectuada el 4 de junio de 2015. Felipe J. Vicente firma el artículo como presidente de la Asociación Nacional de Catedráticos de Instituto.

${ }^{30}$ Francisco López Rupérez, La reforma de la educación escolar, Madrid, FAES, 2009 (http://www.fundacionfaes.org/file_upload/publication/pdf/20130521152551la-reforma-de-la-educacion-escolar.pdf). Consultado el 28 de mayo de 2005.
} 


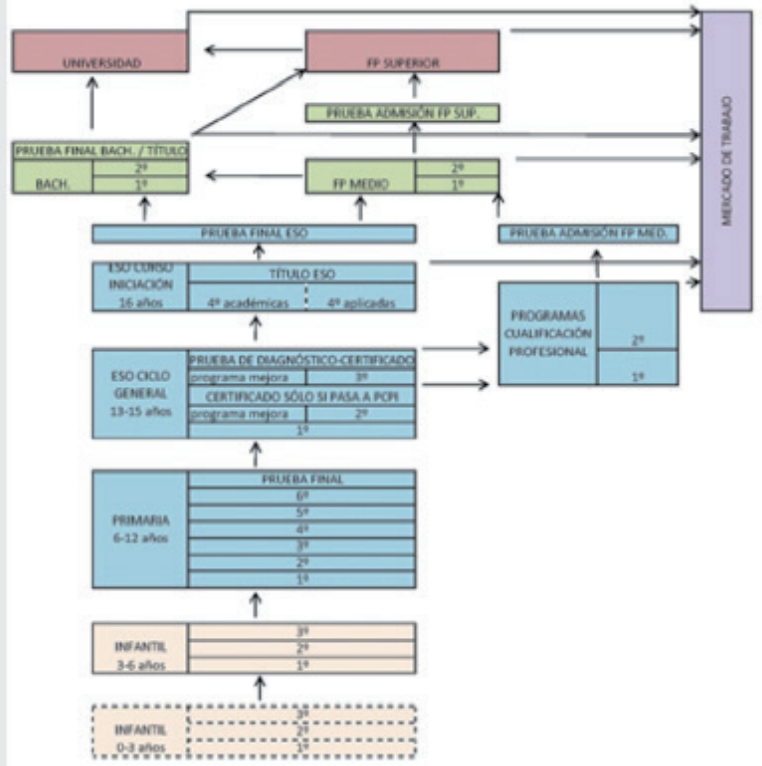

Fuente: https://ampaprincipefelipe.wordpress.com/2012/11/23/analisis-de-la-lomce/. Consulta efectuada el 4 de junio de 2015.

Figura 2. Estructura del sistema educativo español en la LOMCE.

- El establecimiento de dos titulaciones al finalizar la secundaria obligatoria: el certificado oficial de estudios y el graduado, con posteriores opciones académicamente diferenciadas, a las que vendría a sumarse la formación profesional básica como vía opcional para quienes,teniendo quince o dieciséis años, hubieren cursado los dos primeros años de la secundaria obligatoria; es decir, para los que hubieren repetido curso.

- El incremento de evaluaciones y filtros para el paso de un nivel educativo a otro - las conocidas por sus críticos como «reválidas»-, al final de la educación primaria, la secundaria obligatoria y el bachillerato, cuya realización compete al gobierno central, o para decidir el paso, o no, del tercer al cuarto curso de primaria, cuya realización corresponde, en este caso, a las Comunidades Autónomas.

En cuanto al currículo, La LOMCE tenía como objetivo inmediato, y así figuraba en el programa electoral del Partido Popular, la supresión de la asignatura de Educación para la Ciudadanía introducida por la LOE en 2006. Según amplios e influyentes sectores de dicho partido, esta materia 
imponía con carácter obligatorio no solo una ética relativista, sino también la llamada «ideología de género», la autonomía del alumnado frente a las familias y determinadas competencias emocionales e ideas opuestas a las concepciones morales y educativas de algunos padres. ${ }^{31}$ Había que suprimirla, y así se hizo.

Aunque sobre la enseñanza de la Religión católica no se dijera nada ni en el programa electoral ni en la presentación inicial de la reforma, la LOM$\mathrm{CE}$ vino a satisfacer en este punto, y en buena parte, las quejas o peticiones efectuadas por la Conferencia Episcopal Española: obligatoriedad de cursar, a quienes no siguieren dicha enseñanza —o la islámica o evangélica—, una asignatura de valores sociales, cívicos o éticos, e incremento de su presencia e importancia en el currículum y en las evaluaciones continuas del alumnado. La aprobación posterior, por Resoluciones de 11 y 13 de febrero de 2015, del currículo de Religión católica en la educación primaria, la secundaria obligatoria y el bachillerato significaría el predominio de una concepción ultraconservadora y acientífica de la materia, como ya había sucedido anteriormente con la Resolución de 26 de noviembre de 2014 que aprobaba el currículo de la Religión islámica en la enseñanza primaria.

En claro contraste, y en consonancia con el objetivo de conseguir unas evaluaciones comparativamente más favorables en los rankings internacionales, en especial en PISA — cuyos resultados se utilizan en el preámbulo para justificar la reforma-, y por su consideración como materias al parecer escasamente relacionadas con la competitividad económica internacional, la LOMCE reduce la importancia y el peso en el currículum de aquellas materias artísticas — música, expresión plástica y visual-y humanísticas no tenidas en cuenta en dichas evaluaciones. ${ }^{32}$

Por otra parte, con vistas a la consecución del objetivo de «estimular el espíritu emprendedor de los estudiantes» manifestado en el preámbulo, la

\footnotetext{
${ }^{31}$ M. ${ }^{a}$ del Mar Moreno Mozos, «La Educación para la Ciudadanía conflictividad y repercusiones en el sistema educativo», en Sistema educativo y libertad de conciencia, 111-133, y José M. ${ }^{a}$ Martí Sánchez, «La "competencia emocional" en el sistema educativo castellano-manchego (enfoque global y crítico)», en Sistema educativo y libertad de conciencia, 133-175.

32 Sobre la utilización de los informes PISA como justificación de la reforma LOMCE y las políticas de estandarización impulsadas por la OCDE a través de PISA y su influencia en dicha reforma, véase Noelia Fernández-González, «PISA como instrumento de la reforma de la LOMCE», Bordón, 67 (1), (2015): 135148, y Geo Saura y Julián Luengo Navas, «Política global más allá de lo nacional. Reforma educativa (LOMCE) y el régimen de estandarización (OCDE)», Bordón, 67 (1), (2015): 135-148.
} 
LOMCE introduce una nueva materia en el currículo de la educación secundaria obligatoria, con el carácter de asignatura específica- y con una determinada concepción de la vida social y económica-, la Iniciación a la Actividad Emprendedora y Empresarial, y otras dos en el bachillerato: Economía y Economía de la Empresa. No se trata de una asignatura de Ciencias Sociales en general, como hubiera sido deseable desde una perspectiva académico-científica, sino de una parcial, ideológicamente sesgada e interesada versión del mundo económico-productivo-laboral tal y como se aprecia en las páginas dedicadas a estas materias en el Real Decreto de 26 de diciembre de 2014 que establece el currículo básico de la secundaria obligatoria y el bachillerato.

Otro de los objetivos inmediatos de la LOMCE, anunciado además en el programa electoral, era el de eliminar la posibilidad establecida en la LOE de negar los conciertos a aquellos centros privados —en general, de ideario católico conservador- que separan a su alumnado en función del sexo. En esta cuestión, lo que constituye discriminación por sexos para quienes defienden la no concesión de los conciertos a tales centros docentes, solo es, para quienes mantienen la legalidad de los mismos, una educación diferenciada por sexos que garantiza el derecho de los padres, que la desean, a este tipo de enseñanza. ${ }^{33}$ De acuerdo con esta última postura, la LOMCE modifica el párrafo 3 del artículo 84 de la LOE indicando que la educación diferenciada por sexos no constituye discriminación ni supondrá trato desfavorable o desventaja alguna para suscribir conciertos con las administraciones educativas o en cualquier otro aspecto.

Asimismo, como se ha señalado desde posiciones favorables a la nueva regulación de la LOMCE sobre la enseñanza en castellano en las comunidades autónomas con otra lengua oficial — disposición adicional trigésimo octava-, es ese derecho de los padres a elegir la educación que quieren para sus hijos el que sustenta legalmente una regulación dirigida a garantizar el derecho de los padres que lo deseen a que sus hijos reciban la enseñanza en castellano como lengua vehicular, mediante la creación de una oferta educativa específica sostenida con fondos públicos. ${ }^{34}$ Un objetivo electoral que

\footnotetext{
33 Sara Medina González, «Los derechos de los padres en la educación de sus hijos», en Claves de la reforma educativa 123-135, y María Calvo Charro, «El tratamiento de la igualdad y la reforma de la enseñanza diferenciada en la LOMCE», en Claves de la reforma educativa, 153-194.

${ }^{34}$ Medina González, «Los derechos de los padres en la educación de sus hijos», 139-147.
} 
ya figuraba en el documento del Partido Popular «en relación al pacto sobre la reforma del sistema educativo» de 6 de mayo de $2010 .^{35}$

Relacionado con este último punto, se halla otro de los objetivos de la LOMCE: la recentralización del sistema educativo. Por de pronto, y «como declaración de principios que busca afirmar la posición del Estado frente al blindaje competencial autonómico que han consolidado diversos Estatutos, entre ellos el catalán y el andaluz», ${ }^{36}$ la LOMCE, en un nuevo artículo 2 bis, adjetiva el sistema educativo como «español» y lo define como

el conjunto de Administraciones educativas, profesionales de la educación y otros agentes, públicos y privados, que desarrollan funciones de regulación, de financiación o de prestación de servicios para el ejercicio del derecho a la educación, y los titulares de este derecho, así como el conjunto de relaciones, estructuras, medidas y acciones que se implementan para prestarlo.

Aspectos concretos de dicha recentralización serían —además del señalado anteriormente en relación con el castellano como lengua vehicular de la enseñanza-, la introducción de las dos referidas evaluaciones de ámbito nacional, a cargo del Estado, al finalizar la educación primaria y la secundaria obligatoria; y en cuanto al currículo, el incremento de las materias troncales, o determinados aspectos relativos a la concreción del currículo básico, los estándares de aprendizaje evaluables, los criterios de evaluación, o los horarios. ${ }^{37}$ La respuesta a este intento recentralizador han sido los seis recursos de inconstitucionalidad interpuestos por las comunidades autónomas de Cataluña —uno por el gobierno y otro por el parlamento-, Asturias, Canarias, Andalucía y País Vasco. En palabras de un reconocido especialista en el tema competencial estatal y autonómico en materia educativa,

una reforma que podría haber sido beneficiosa en términos de seguridad jurídica, acaba por aportar aún mayor complejidad al difícil asunto de la distribución territorial del poder y permite augurar, por este motivo y por el polémico tratamiento de varios aspectos

\footnotetext{
35 Partido Popular, Propuestas del PP para un pacto por la reforma y mejora de la educación en España, 4. 36 Pablo Meix Cereceda, «Aspectos competenciales y reformas curriculares: la Ley para la Mejora de la Calidad Educativa en el marco de la Constitución», en Claves de la reforma educativa, 57-82 (cita en pp. 69-70).

37 Sobre todo ello, véase Meix Cereceda, «Aspectos competenciales y reformas curriculares», 72-80.
} 
concretos, un incremento de la conflictividad en el ejercicio de las competencias sobre enseñanza. ${ }^{38}$

Otro objetivo de la LOMCE, expresamente indicado en el mencionado documento del Partido Popular «en relación al pacto sobre la reforma del sistema educativo» de 6 de mayo de 2010, es el de fortalecer o potenciar la función directiva en los centros públicos, lo que en su preámbulo se denomina «el liderazgo pedagógico y de gestión». No está de más transcribir lo que al respecto se decía en dicho documento:

\section{EL PP QUIERE PROFESIONALIZAR LA FUNCIÓN DIRECTIVA, alejarla de cualquier politización y con una selección basada en los principios de mérito y capacidad, así como definir un sistema de incentivos y reconocimientos que permita atraer a los mejores a la función directiva y permanecer en ella. ${ }^{39}$}

De acuerdo con dicho propósito, la LOMCE atribuye a la dirección competencias decisorias asignadas en la LOE al consejo escolar del centro, convirtiendo a este en un mero órgano asesor, y añade un nuevo artículo, el 122 bis, en el que amplía sus facultades. Al mismo tiempo, modifica el artículo 135 de la LOE que establecía la composición de las comisiones encargadas de su selección. Si en la LOE eran mayoría los representantes del claustro y del consejo escolar del centro que no fueran profesores, en la nueva regulación la mayoría corresponde a las administraciones educativas. Es decir, ha convertido a la dirección en una agencia o escalón territorial más, de índole jerárquica, de la administración educativa. Una agencia encargada de cumplir y hacer cumplir las leyes, medidas e instrucciones de todo tipo que emanen de dicha administración. Este hecho, conociendo la general tendencia de las administraciones públicas —entre ellas las educativas- a nombrar personas ideológica o clientelarmente afines para todo tipo de cargos y puestos, ha levantado todas las alarmas.

Así, desde la Federación de directores de Institutos de Secundaria (FEDADI), su presidente, José Antonio Martínez, ha alertado contra «el

\footnotetext{
${ }^{38}$ Meix Cereceda, «Aspectos competenciales y reformas curriculares», 82.

39 Partido Popular. Oficina de Información, Posición del Partido Popular en relación al pacto sobre la reforma del modelo educativo, 6. Las mayúsculas corresponden al original. El texto transcrito está además, todo él, en negrita.
} 


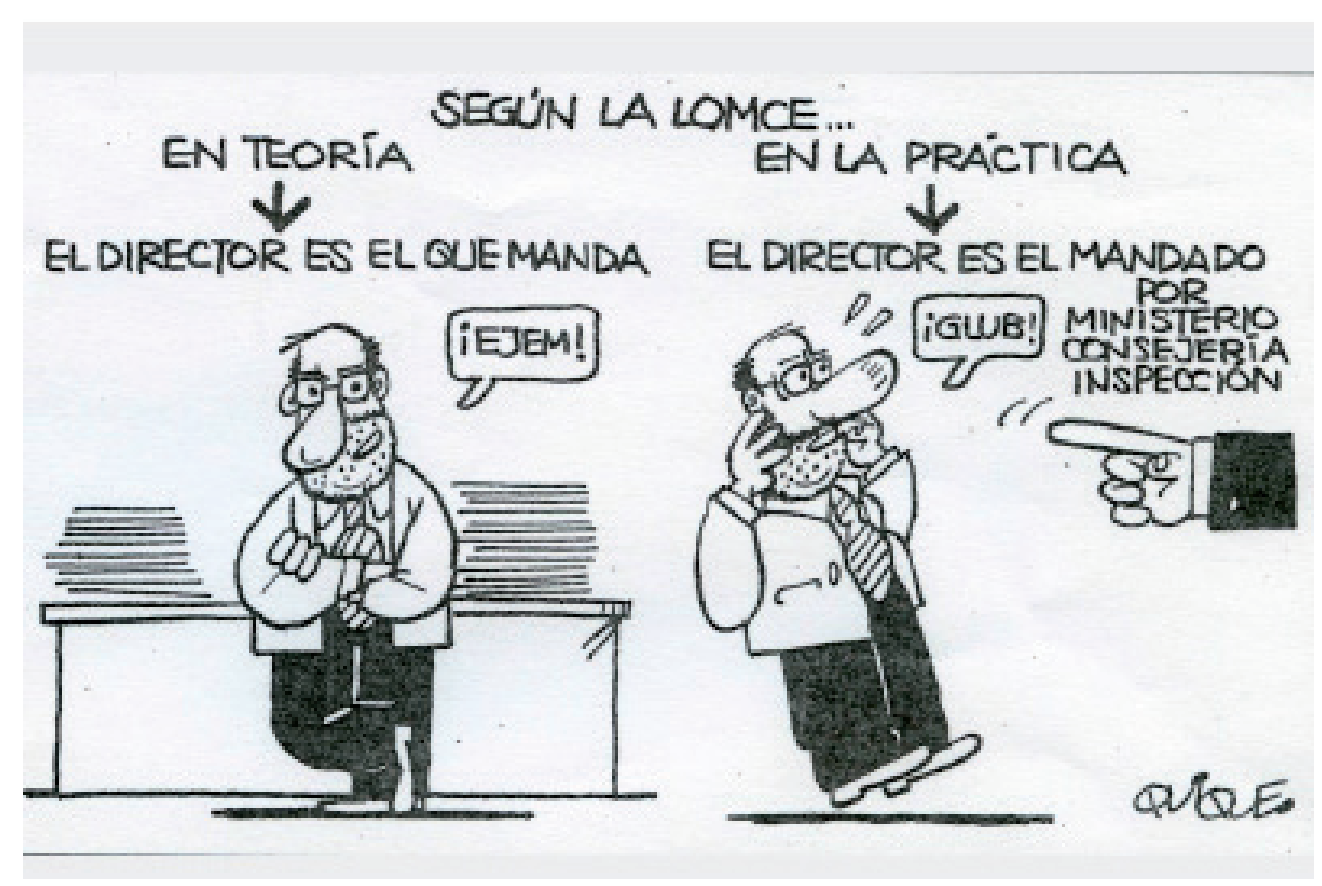

Fuente: Escuela, 4038 (6 de noviembre de 2014): 2.

Figura 3. La dirección escolar en la LOMCE.

riesgo del clientelismo con una comisión en que la Administración se reserva más del 50\%, como ya se experimentó con la LOCE (2002)». «Otra cosa», añade, «es una comisión de expertos». ${ }^{40} \mathrm{~A}$ su vez, el presidente de la comisión gestora de la Federación de directores de colegios de Infantil y Primaria (FEDEIP), José Manuel Sixto, indica que se pasa «de estar muy sujetos a la votación del consejo escolar y la Inspección a estar totalmente vinculados a la Administración, con lo que, a la larga, cualquiera que discrepe podrá ser desplazado». Asimismo, el hecho de que pueda ser nombrado para la dirección un docente de otro centro lo ve como un mecanismo para controlar «claustros incómodos». Más crítico todavía, José Luis Pazos, desde la Confederación Española de Asociaciones de Padres y Madres de Alumnos (CEAPA), destaca que el nuevo modelo está pensado para que en los centros docentes se haga «lo que se decide en los despachos» de la Administración.

40 Sara Marqués, «La nueva figura de director que dibuja la Lomce», Escuela, 4.009 (30 de enero de 2014 ): 5. El primer párrafo entrecomillado corresponde al resumen, efectuado por la autora, de lo dicho por el presidente de FEDADI. El segundo a una cita entrecomillada de la entrevista mantenida con el mismo. 
Y que el que se haya suprimido la preferencia por los docentes del centro al que se opta, significa que habrá «unas directrices cerradas y dará igual un centro que otro"; es decir, que primará la uniformidad impuesta sobre la diversidad. ${ }^{41}$ Nada mejor refleja esta nueva situación que la viñeta humorística de Quique inserta en la revista Escuela (figura n. ${ }^{\circ} 3$ ).

Este modelo de dirección escolar como agente de la administración educativa para la aplicación de su política educativa, está, por otra parte, en clara contradicción con el objetivo-principio, expresamente formulado en el preámbulo de la LOMCE, de dar autonomía a los centros docentes. Así lo vio la Comisión Permanente del Consejo de Estado al emitir su dictamen sobre el anteproyecto de ley:

Cuando el modelo de gestión se basa en la atribución de todas las decisiones a un órgano unipersonal sin participación activa del resto de la comunidad educativa, la autonomía se limita, ya que el control se ejerce por agentes y órganos ajenos al centro, lo que sin duda incrementa la dependencia de otras instancias. ${ }^{42}$

Salvo que, como ha advertido Antonio Bolívar, tras la publicación del proyecto de Real Decreto sobre los nuevos y pormenorizados currículos básicos de la LOMCE, "la verdadera autonomía» de los centros en esta nueva ley no resida en el currículo, sino en la consecución de "la competencia» entre los centros docentes en un contexto de cuasi-mercado - distrito único, libertad de elección de centro dentro del mismo, evaluaciones externas con rankings públicos para información de los padres, etc. ${ }^{43}$ Lo que, en

\footnotetext{
${ }^{41}$ Marqués, «La nueva figura de director que dibuja la Lomce», 5.

42 Dictamen de la Comisión Permanente del Consejo de Estado sobre la Ley Orgánica de mejora de la calidad educativa (Madrid, 18 de abril de 2013): 150: http://www.mecd.gob.es/mecd/dms/mecd/servicios-al-ciudadano-mecd/participacion-publica/lomce/20130426-dictamen-consejo-estado.pdf (consulta efectuada el 28 de septiembre de 2014). En igual sentido, véase p. 157: «Debería, en aras del principio de participación democrática, sopesarse seriamente esta reducción [la del número de miembros de la comunidad educativa que forman parte de las comisiones de selección], que no se corresponde ciertamente con el principio de autonomía de los centros que el anteproyecto dice tratar de potenciar». Incluso, desde una perspectiva general y en relación con el cercenamiento de las competencias decisorias o co-decisorias del Consejo Escolar y del Claustro llevado a cabo, el Dictamen llega a plantearse (pp. 155-156) «la posibilidad» de que este empobrecimiento de la participación «contravenga lo dispuesto en el pfo. 7 del artículo 27 de la Constitución que establece el derecho de los profesores, padres y alumnos a intervenir en el control y gestión de los centros docentes sostenidos con fondos públicos».

43 Antonio Bolívar, «La cola que menea el perro» (El Pais, 26 de enero de 2014): http://sociedad.elpais. com/sociedad/2014/01/26/actualidad/1390764242_224288.html; consultado el 2 de octubre de 2014.
} 
relación con los centros públicos, exige direcciones escolares disciplinadamente sujetas y acordes con los gobiernos y administraciones educativas que promuevan este tipo de políticas. Es decir, que la autonomía se reduzca a que, en el marco de ese cuasi-mercado, cada centro público se busque la vida como pueda teniendo en cuenta que sus recursos materiales, financieros y humanos son establecidos por dichos gobiernos y administraciones con el fin, entre otros, de dirigir la demanda social hacia la enseñanza privada, concertada o de pago (en este último caso, mediante exenciones fiscales). Y que además, en este caso, dichos recursos se han visto reducidos por una política de recorte del gasto social y del gasto público en educación. ${ }^{44}$

Todo lo anterior guarda una relación a la vez estrecha y contradictoria con otro de los principios u objetivos inmediatos de la LOMCE: la implantación de las tres referidas evaluaciones externas — dos de ámbito nacional y otra autonómico - como instrumento no solo para la mejora de la calidad del sistema educativo, sino también de la posición de España en los rankings de las evaluaciones internacionales. Dejo a un lado la cuestión de la calidad, ya que

los perfiles de este concepto se han ido desdibujando, hasta convertir la mención de la calidad en una cláusula de estilo prácticamente inútil, pues resulta inabarcable la variedad de enfoques, matices y contenidos que se ha reputado como medios para obtener una enseñanza de calidad o, más aún, como exigencias «objetivas» de la calidad. ${ }^{45}$

En último término, como afirma Gert Biesta, la educación es una práctica política y moral en la que las palabras eficacia, eficiencia, calidad o excelencia, siempre nos remiten a preguntarnos para qué o en función de qué. ${ }^{46}$

${ }^{44}$ Un listado informativo sobre el alcance y los aspectos afectados por dichos recortes puede verse en http://wiki.15m.cc/wiki/Lista_de_recortes\#Educaci.C3.B3n (consulta efectuada el 5 de octubre de 2014): profesorado, becas, ayudas de comedor y para libros y material didáctico, gastos de funcionamiento, programas compensatorios y de atención tutorial, de atención a la diversidad y de refuerzo o apoyo, etc.

${ }^{45}$ Pablo Meix Cereceda, «La evaluación externa de los alumnos y la incierta búsqueda de la calidad de la enseñanza», El Cronista del Estado Social y de Derecho, 46 (2014): 64-75 (cita en p. 66).

${ }^{46}$ Gert Biesta, "Why "what works” won't work: evidence-based practice and the democratic deficit in educational research», Educational Theory, 57 (1), (2007), 1-22, y «Good education in an age of measurement: on the need to reconnect with the question of purpose in education", Educational Assessment, Evaluation and Accountability, 21 (1), (2009), 33-46. Ambos trabajos han sido recogidos, junto a otros del autor, en Good Education in an Age of Measurement: Ethics, Politics, Democracy (Bouldon, London: Paradigm Publishers, 2010). 
Pese a que se diga en el preámbulo que las evaluaciones externas «tendrán un carácter formativo y de diagnóstico», estamos ante evaluaciones sumativas no formativas. Por ello se colocan al final de la educación primaria y de la secundaria obligatoria. No van dirigidas a la mejora de la enseñanza y el aprendizaje, aunque así también se diga en el preámbulo, sino al control y la rendición de cuentas ante la administración, a la publicación de los resultados con el fin de orientar a las familias en sus demandas y favorecer la selección del alumnado por los centros docentes con mayor demanda, y a mejorar los resultados del país en las comparaciones internacionales; un objetivo, este último expresamente declarado como tal en el preámbulo de la ley. ${ }^{47}$ De ahí, por ejemplo, que el Instituto Nacional de Evaluación Educativa haya planteado unas pruebas finales o "reválidas» inspiradas en las de PISA. ${ }^{48}$

Por último, la LOMCE en el nuevo párrafo q) del artículo 1, reduce la libertad de enseñanza al «derecho de los padres, madres y tutores legales a elegir el tipo de educación y el centro para sus hijos». Dicho derecho nos lleva a otro de sus objetivos inmediatos, expresado de modo inequívoco en el programa electoral y en diversos documentos del Partido Popular, y definido en el preámbulo de modo eufemístico como «racionalización de la oferta educativa»: el de garantizar la llamada libre elección de centro. Ello con un doble fin. Uno confesado: atender la «demanda social» de aquellos padres que desean una enseñanza privada, concertada o no. ${ }^{49}$ Otro no explícito en la LOMCE: configurar una cuasi-mercado educativo en el que, con vistas a la consecución de una mayor calidad, los centros compitan entre sí, y desaparezcan o se supriman aquellos en los que no haya una demanda social que justifique su existencia.

Este último objetivo lleva consigo otros dos complementarios. Uno expresamente reconocido y ya mencionado: el establecimiento de evaluaciones externas cuyos resultados sirvan de instrumento informativo a los padres para que elijan uno u otro centro docente. Para ello se deroga el artículo

\footnotetext{
${ }^{47}$ Meix Cereceda, «La evaluación externa de los alumnos» $\mathrm{y}$ «Aspectos competenciales y reformas curriculares», 68. Con sentido asimismo crítico, y desde la prensa económica de signo liberal, Gabriel Álvarez, «Evaluaciones externas y lo economicista», El Economista (11 de marzo de 2015): 38.

48 S.M., «PISA como plantilla para las reválidas», Escuela (8 de mayo de 2014): 7.

${ }^{49}$ La Ley de 23 de diciembre de 2010 de Medidas Fiscales, Administrativas y de Racionalización del Sector Público de la Comunidad Autónoma madrileña, estableció en 30.000 euros por miembro de la unidad familiar, el límite de desgravación por gastos de enseñanza para las familias que enviaren a sus hijos a centros privados de pago.
} 
140-2 de la LOE que prohibía de manera expresa que los resultados de las evaluaciones fueran utilizados "para valoraciones individuales de los alumnos o para establecer clasificaciones de centros», y se da una nueva redacción al artículo 147-2 indicando que «los resultados de las evaluaciones que realicen las Administraciones educativas serán puestos en conocimiento de comunidad educativa mediante indicadores comunes para todos los centros docentes españoles». Y otro no mencionado de forma expresa en la LOMCE pero permitido ya por la LOE y llevado a cabo por el Partido Popular en las comunidades autónomas y municipios en los que ha gobernado o gobierna: el establecimiento de distritos únicos, frente al de zonas de escolarización, como sistema de admisión de alumnos que facilita dicha elección en un marco territorial más amplio. ${ }^{50}$

Así, por un lado, la nueva redacción del artículo 109 de la LOE conecta la programación de la oferta educativa con la «demanda social» en relación con la «oferta existente de centros públicos y privados concertados». Como se ha dicho desde una posición favorable a esta nueva redacción,

la inclusión de este nuevo criterio [la demanda social] refuerza el derecho de los padres a elegir el tipo de educación y el centro que quieren que estudien sus hijos.

A partir de ahora, si hay mucha demanda en un centro, se aumentará el número de plazas del mismo. ${ }^{51}[\ldots]$

Tras la LOMCE, si la demanda de las familias fuera superior en los centros concertados que en los públicos, se podrían establecer más conciertos por parte de la Administración educativa, reforzándose así la libertad de los padres a la hora de elegir. Antes, sin embargo, la Administración podía llegar a negar el concierto a un colegio privado si, por ejemplo, quedaban plazas vacantes en colegios públicos. ${ }^{52}$

Por otro lado, allí donde la LOE decía, en dicho artículo 109, que «las Administraciones educativas garantizarán la existencia de plazas públicas suficientes especialmente en las zonas de nueva población», ha bastado con

\footnotetext{
${ }^{50}$ Por ejemplo, entre otros, el Decreto de 27 de diciembre de 2012 de Castilla-La Mancha que establece áreas de escolarización coincidentes con las de cada localidad, y el Decreto 11 de abril de 2013 de la Comunidad de Madrid que elimina las zonas de escolarización.

${ }^{51}$ A la inversa, se entiende que se suprimirán allí donde haya menos demanda.

${ }^{52}$ Medina González, «Los derechos de los padres en la educación de sus hijos», 126.
} 
suprimir el adjetivo "públicas» y el inciso sobre las «zonas de nueva población» para que, si "antes de la LOMCE era muy complicado» que un colegio privado pudiera conseguir un concierto en dichas «zonas», ahora será algo relativamente sencillo, en especial si, como se dice en la nueva versión del artículo 116, «las Administraciones educativas podrán convocar concursos públicos para la construcción y gestión de centros concertados sobre suelo público dotacional». ${ }^{53}$

\section{Una reforma gradual a medio y largo plazo: entre la privatización y el carácter subsidiario del sector público}

No es que, desde el acceso del Partido Popular al poder en 1996 bajo el ministerio Aguirre, falten voces en dicho partido, o en sus aledaños y simpatizantes, que defiendan sin ambages la creación de un mercado educativo y en definitiva la privatización del sistema educativo mediante la doble fórmula del cheque escolar y las desgravaciones fiscales a quienes llevan a sus hijos a colegios privados de pago. La implantación del cheque escolar a título de ensayo bajo el gobierno de la Unión de Centro Democrático, ya había sido prevista en 1980 al aprobarse el Estatuto de Centros Escolares, como el mismo ministro, Otero Novas, confiesa en sus memorias. ${ }^{54} \mathrm{Y}$ en 1997, tras la llegada al poder del Partido Popular, Ramón Tamames mantenía que

se da la situación inconstitucional, de que la gente que dice que sus hijos vayan a colegios independientes que no son escuelas públicas ni centros concertados, tienen que pagar doble. Es decir, no tienen gratuidad porque pagan la factura del colegio y, paralelamente, pagan sus impuestos, de los cuales provienen precisamente los fondos para que las escuelas públicas sean gratuitas y las escuelas concertadas tengan un alto grado de gratuidad. ${ }^{55}$

\footnotetext{
53 Medina González, «Los derechos de los padres en la educación de sus hijos», 127. La autora olvida, o deja a un lado, el hecho de que dicha cesión de suelo público, junto con la subvención de la construcción del nuevo centro docente y la concesión del concierto ha sido, y es, una práctica habitual en las comunidades autónomas y ayuntamientos gobernados por el Partido Popular que, además, se ha realizado en favor de grupos, entidades o personas afines desde el punto de vista confesional, ideológico o económico dando lugar, en más de un caso, a prácticas corruptas, en ocasiones incluso delictivas. Lo único que hace la LOMCE es dar un apoyo o cobertura legal a tales cesiones, subvenciones y conciertos.

${ }^{54}$ José Manuel Otero Novas, Lo que yo viví. Memorias políticas y reflexiones (Barcelona: Prensa Editorial, 2015), 253.

55 Ramón Tamames, «Libertad, financiación y competitividad en la educación. Entrevista con Ramón Tamames», Organización y Gestión Educativa, 4 (1997), 40-43 (cita en p. 40).
} 
Por tanto hay que eliminar esa situación de inconstitucionalidad y hacer posible que la gente que elige que sus hijos vayan a colegios privados, tengan por lo menos la devolución de una parte de la factura a través de una reducción fiscal o que reciban unos cheques escolares para que lleven a sus hijos donde quieran.

La división —más estratégica que finalista—, en el Partido Popular entre los partidarios de la total privatización de la educación y los que, más prudentemente, optan por la vía gradual de los conciertos, la configuración subsidiaria del sector público dejando unos pocos centros docentes llamados de excelencia, y la orientación de la demanda social hacia la enseñanza privada, existe prácticamente desde su configuración como partido político. En el debate de una ponencia presentada por José Luis González Quirós en un ciclo celebrado en la FAES desde octubre de 1997 a marzo de 1998, significativamente titulado «El sistema de educación en España: de lo posible a lo deseable», Rafael Termes Carrero, expresidente de la Asociación Española para la Banca Privada, mantendría que «la solución más efectiva a los problemas de la educación reside en la privatización de todo el sistema» con el fin de hacer posible «una limpia competencia efectiva entre los centros en economía y calidad». Frente a dicha propuesta, Andrés Ollero Tassara, por entonces diputado del Partido Popular, calificaba de «error político proponerse como objetivo explícito la privatización del sistema» y defendía "la técnica vigente de los conciertos escolares que, a su entender, no condicionan el ideario» del centro, advirtiendo que, en cualquier caso, no debía «hacerse planteamiento político alguno en materia educativa que pueda interpretarse como amenaza a lo público». ${ }^{56} \mathrm{En}$ general, puede afirmarse que las posturas en favor de la privatización total e inmediata proceden del sector financiero-empresarial y de determinados economistas, mientras que desde el mundo de la política, más atento a la complejidad de lo real, se recela de los cambios drásticos y se opta por soluciones graduales, orientando la demanda social hacia el sector privado y aplicando técnicas de gestión al sector público, sin descartar la progresiva evolución, como ideal teórico o deseable, de la privatización del sistema educativo.

56 José Luis González Quirós, «¿Qué se puede esperar de la educación al comienzo del siglo XXI?», en El sistema educativo en la España de los 2000, coords. José Luis González Quirós y José Luis Martínez López Muñiz (Madrid: Fundación para el Análisis y los Estudios Sociales, 2001), 13-24 (citas en pp. 19-20). 
No obstante, las propuestas maximalistas de aplicación radical de principios supuestamente liberales, tomando como modelo las políticas llevadas a cabo por el partido conservador sueco desde la década de los 90 o en el Chile pinochetista y post-pinochetista, entre otros países, siguen gozando de un claro predicamento en los foros pertenecientes o cercanos al Partido Popular. La «Propuesta para España» efectuada en 2009 en la FAES por Mauricio Rojas, exdiputado de origen chileno del partido conservador sueco, constituye un buen ejemplo: implantación total del «vale escolar» por «un monto equivalente al costo total por alumno de las escuelas de gestión pública»; incremento de las tasas universitarias y sustitución de las becas por préstamos en este nivel educativo; abrir «el paso» en la educación a "las entidades con ánimo de lucro»; gestionar las escuelas públicas como si fuesen privadas - libertad de sus gestores para elegir el personal, fijar sus retribuciones y gestionar su presupuesto-; estimular el paso del profesorado desde el sector público al privado ofreciéndole de este modo la posibilidad de convertirse en empresarios de sus propios centros y de obtener mejores retribuciones; forzar la conversión de los centros públicos en "escuelas independientes» abandonando los docentes el estatus de funcionario amenazando con licitar a empresas privadas aquellos centros cuyo profesorado no acepte convertirse en «independiente»; cierre de los centros que «mantengan rendimientos deficitarios» durante «un determinado lapso de tiempo», así como del personal directivo y del profesorado de baja "eficiencia»; concesión de "bonos de excelencia» a aquellos centros docentes que «sobrepasen notablemente los niveles de rendimiento educativo medio»; y creación de un «organismo nacional» encargado de autorizar la creación de nuevos centros docentes en «un nuevo sistema educativo español» que «sea efectivamente español. Es decir, que sea regulado a nivel nacional por normas comunes básicas válidas en todo el país», como corresponde a una nación, España, cuya "historia» encadena "proezas asombrosas» -en sus «siglos de gloria»-, «oportunidades perdidas» $\mathrm{y}$ «crisis mal resueltas». Por supuesto, cuando el ex-diputado sueco advierte la contradicción existente entre el hecho de que haya centros docentes que seleccionan al alumnado con criterios confesionales y la no admisión, mantenida por el autor, de criterios de selección basados en las condiciones socieconómicas, la raza, el origen o el tipo de familia, no solo no ofrece solución alguna para aquellos casos en los que la demanda supere a la oferta, sino que, desde la ingenuidad o el cinismo, todo se reduce a pedir que se abra «un diálogo» con las «escuelas de inspiración confesional» para 
«compatibilizar» lo que consideramos incompatible. Es decir, «los aspectos rigurosa y legítimamente confesionales de la escuela en cuestión con la apertura de la misma a todo alumno». ${ }^{57}$

Frente a posturas maximalistas como las referidas, desde el ámbito de la política educativa llevada a cabo por el Partido Popular, tanto a nivel estatal como autonómico y municipal, lo que se observa, como se dijo, es la marcha gradual hacia la consecución - ya alcanzada en cierta medida- de una red escolar en la que el sector público sigue siendo útil y subsiste, de momento, como subsidiario del privado, reduciéndose paulatinamente en función de una «demanda social» debidamente teledirigida (figura 4).

Figura 4. Red escolar reforzada por la $\mathrm{LOMCE}^{58}$

\begin{tabular}{|l|l|l|l|l|}
\hline \multicolumn{1}{|c|}{$\begin{array}{c}\text { Centros } \\
\text { docentes }\end{array}$} & \multicolumn{1}{|c|}{$\begin{array}{c}\text { Carácter } \\
\text { asistencial }\end{array}$} & $\begin{array}{c}\text { Bajos } \\
\text { resultados }\end{array}$ & $\begin{array}{c}\text { Buenos } \\
\text { resultados }\end{array}$ & $\begin{array}{c}\text { Centros } \\
\text { de elite }\end{array}$ \\
\hline Públicos & Algunos & Muchos & Algunos & Muy escasos \\
\hline Concertados & Muy escasos & Algunos & Muchos & Algunos \\
\hline Privados & Ninguno & Ninguno & Algunos & Muchos \\
\hline
\end{tabular}

Una cosa es, en efecto, lo deseable y otra lo posible. Al fin y al cabo, como se ha señalado, la capacidad de penetración en cada país de lo que se ha dado en llamar el Nuevo Orden, depende sobre todo de la fortaleza de sus adversarios y de las resistencias y dificultades que encuentra para llevarse a cabo. ${ }^{59}$ Recurriendo a una clásica y popular expresión de filiación marxista, diríamos que la sociedad española no ofrece todavía «las condiciones objetivas» para la aplicación, con débiles resistencias, de una política maxima-

\footnotetext{
${ }^{57}$ Mauricio Rojas, Libertad de elección y pluralismo. Propuestas para una reforma de la educación española inspiradas en la reforma de Suecia (Madrid: FAES, 2009), 20-31 (http://www.fundacionfaes.org/ file_upload/publication/pdf/20130521152549libertad-de-eleccion-y-pluralismo.pdf). No es de extrañar el entusiasmo con que se reciben estas propuestas entre quienes en España se autocalifican de liberales. A título de ejemplo, véase Victoria Llopis, «Libertad, Calidad y Educación. Análisis de la situación en España y comparativa europea», en Sistema educativo y libertad de conciencia, 73-85 (referencia en pp. 80-81).

${ }^{58}$ Cuadro tomado, con alguna leve variante, de José María Rozada, «Las reformas y lo que está pasando (De cómo en la educación la democracia encontró su pareja: el mercado)», Con-Ciencia Social, 6 (2002), 15-57 (p. 45).

${ }^{59}$ Ken Jones et alii, La escuela en Europa occidental. El Nuevo Orden y sus adversarios (Alzira: Editorial Germania, 2009).
} 
lista neoconservadora. En este sentido, la LOMCE solo sería un paso más, gradual, en la larga marcha hacia la privatización total del sistema educativo español.

\section{CONCLUSIONES INCONCLUSAS}

No es fácil extraer unas conclusiones en relación con una norma legal vigente cuya aplicación es posible que haya sido paralizada, modificada o incluso derogada como tal norma, cuando se publique lo que se está escribiendo. Este es uno de los problemas que plantea la historia del presente. Es en este sentido en el que estas son unas conclusiones inconclusas. Tendrán que pasar años, quizás décadas, para llegar a unas auténticas conclusiones.

Tanto desde un punto de vista ideológico como práctico, la política educativa del Partido Popular constituye la versión española de ese Nuevo Orden conocido como neoliberal o neoconservador. Esa es su fuente y su origen. El modelo de referencia podría ser muy bien el descrito, desde una perspectiva crítica, por Diane Ravitch para Estados Unidos en su análisis de la ley No Child Left Behind aprobada en 2001 bajo la presidencia de George W. Bush, continuada y reforzada bajo administración Obama por su secretario de Estado de Educación, Arne Duncan, mediante el programa federal Race to the Top aprobado en 2009: establecimiento de estándares, rendición de cuentas y evaluación de alumnos y centros mediante test limitados a la lectura y a las matemáticas, rankings públicos, premios para quienes obtienen mejores resultados, castigos y despidos o cierres para los directores, profesores y centros con peores resultados y correlativa creación de las llamadas charter schools privadas con nuevos profesores y directores sin experiencia e inferiores salarios, apoyo a las medidas o programas de libre elección de centro, introducción de cheques escolares, privatización del sistema y apertura del mismo al capital e intereses privados. ${ }^{60} \mathrm{Su}$ adaptación a España requiere otros fundamentos teóricos y jurídico-políticos, la consideración del peso y relevancia que la Iglesia católica tiene en el sistema educativo, y la promulgación de una ley paraguas que proteja y refuerce las medidas emprendidas en tal dirección en las Comunidades Autónomas y municipios gobernados

${ }^{60}$ Diane Ravitch, The death and life of the great american school system: How testing and choice are undermining education (New York: Basic Books, 2011) y sobre todo Reign of error. The hoax of the privatization movement and the danger to America's public schools (New York: Vintage Books, 2014). 
por el Partido Popular. Medidas, desde una perspectiva general, de apoyo a la enseñanza privada concertada y de pago, de orientación gradual de la demanda social hacia los centros privados y subsistencia de un sector público de índole asistencial, con recursos limitados y disciplinadamente sujeto a la administración educativa correspondiente. Y desde una perspectiva concreta, entre otras medidas ya mencionadas como la implantación del distrito único, de:

- El cierre de aulas o unidades escolares en centros públicos y la apertura, en zonas cercanas, de centros concertados mediante cesiones de suelo público acompañadas de financiación de la construcción y posterior concertación, como ya se dijo, a titulares de signo puramente empresarial (empresas sin tradición educativa) y/o afines confesional o ideológicamente, o a las que se está ligado por intereses laborales o económicos.

- La externalización de tareas de servicios y actividades extraescolares e incluso de tareas de asesoramiento, consulta y evaluación.

- La contratación temporal de personal docente al margen del procedimiento público establecido, formado en instituciones privadas ideológicamente afines. ${ }^{61}$

- El nombramiento temporal de profesores «becarios» con inferior retribución, o sin retribución alguna pero con el reconocimiento de un determinado número de créditos para futuras oposiciones.

En este sentido, la LOMCE y sus disposiciones reglamentarias deben ser vistas como el marco legal que viene a sustentar y apoyar este tipo de políticas y medidas.

En último término, la espina dorsal de la LOMCE, el elemento que le da coherencia y en torno al cual gira toda ella es el derecho de los padres - de unos determinados padres- a que sus hijos reciban una educación acorde con sus ideas o principios no solo religiosos, sino también morales o sim-

\footnotetext{
${ }^{61}$ Sobre el envío y ofrecimiento gratuito de profesores en los Institutos de secundaria madrileños por la Fundación «Empieza por Educar» (http://empiezaporeducar.org), creada en el 2009 siguiendo el modelo de la estadounidense Teach forAmerica (http://www.teachforamerica.org), véase, por ejemplo, http://profesorgeohistoria.wordpress.com/2011/09/26/la-secta-neoliberal-empieza-por-educar-ya-se-ha-colado-en-los-institutos-madrilenos/ (consulta efectuada el 5 de octubre de 2014). En cuanto a Teach for America, véase Ravitch, Reign of error, 133-144.
} 
plemente educativos o pedagógicos. Este es el fundamento de buena parte de sus objetivos a corto, medio o largo plazo. Este derecho es, para sus defensores, el derecho o libertad básica en función de la cual hay que regular y estructurar el sistema educativo. Constituye, en síntesis, «el contenido esencial del Derecho a la educación». Y esto es lo que hace la LOMCE, según sus promotores: potenciar «el papel que la familia juega en la educación de los alumnos reforzando así el derecho de los padres a la educación que quieren que sus hijos reciban». ${ }^{62}$

La nueva ley, expresión legal máxima por ahora de la política educativa del Partido Popular, va más allá de la LOCE de 2002 en el desarrollo de dicha política. Es un paso gradual más - como «gradualista y prudente» se autocalifica en el preámbulo- hacia un modelo de calidad basado en la privatización, la configuración de un cuasi-mercado educativo, la consideración subsidiaria y asistencial de la mayor parte del sector de titularidad pública, y una regulación detallada del currículum mediante disposiciones legales y pruebas externas tipo test, de índole nacional-estatal, que van a condicionar los procesos de enseñanza y aprendizaje reduciéndolos a la preparación de dichos test. No responde a las propuestas maximalistas de privatización, pero tampoco las excluye. Las ampara y por tanto las anticipa o prepara. No obstante, no satisface a quienes, desde posiciones ideológicamente cercanas, la consideran insuficiente y de corto alcance, y cuenta con la oposición generalizada, por una u otra razón, de la práctica totalidad del resto de los partidos políticos. Ofrece, en su aplicación, problemas derivados de una financiación insuficiente, de la falta de consenso, de los conflictos competenciales y recursos de inconstitucionalidad, de un calendario de implantación apresurado, y de la ausencia de criterios definidos y el recurso a los eufemismos - ¿competencias o contenidos? ¿disciplinas o proyectos? - en relación con el currículum. Nace además con fecha de caducidad. Pero no es eso, a mi juicio, lo más paradójico y destacable de la LOMCE. Ni siquiera todo lo dicho hasta aquí sobre ella.

Lo paradójico, y por ello significativo, es el clamoroso silencio que una ley «de mejora de la calidad educativa» ofrece en relación con justamente los dos aspectos que más relación guardan con dicha mejora: el profesorado y la situación social de la infancia y adolescencia en España.

${ }^{62}$ Medina González, «Los derechos de los padres en la educación de sus hijos: principales novedades de la LOMCE», 124 y 120. 
En cuanto al profesorado, la LOMCE no le dedica ni en el preámbulo ni en el articulado una sola frase salvo para que se sienta, con razón o sin ella, amenazado con rendiciones de cuentas y más burocracia y evaluaciones en su tarea o, eso sí, para considerarlo "autoridad pública» en un artículo, el 124, dedicado a las normas de convivencia en los centros docentes. No se hallará en ella ni una sola frase o palabra sobre su formación inicial y permanente, su selección o la configuración de la carrera y profesión docente. Justo sobre aquello en lo que prácticamente todos, sea cual sea su signo ideológico, estarían de acuerdo: que el profesorado constituye el elemento fundamental de cualquier programa de mejora de la calidad educativa.

No menos significativo es el carácter etéreo de la LOMCE en relación con el contexto social en el que se diseña y nace, y en el que ha de aplicarse. Los datos procedentes de dos recientes informes sobre la situación social de la infancia y adolescencia en España no dejan lugar a dudas sobre la necesidad de tener en cuenta dicha situación en la conformación y regulación del sistema educativo. Incluso aunque se considere, de forma harto restrictiva, que dicha mejora se limita a los resultados académicos o a las evaluaciones externas. ${ }^{63}$ Dos informes, editados en 2014 por el Comité Español de UNICEF y la Obra Social La Caixa, coinciden en lo fundamental: unos 2.306.000 niños - sobre el $28 \%$ - se hallan en España en el umbral de pobreza, en riesgo de pobreza o viven en un contexto de pobreza severa o crónica, así como el $34 \%$ de los adolescentes de 14 a 17 años. Se trata, además, de una situación agravada en el período 2008-2012, que nos sitúa con la tasa de pobreza infantil más alta de toda la Unión Europea tras Rumanía. Y ello en uno de los países miembros de dicha Unión, España, que, como se indica en ambos informes, menos recursos dedica a una política social particularmente dirigida a los niños y a las familias. ${ }^{64}$ Hay silencios que hablan por sí solos. Este es uno de ellos.

\footnotetext{
${ }^{63}$ Como indica Diana Ravitch (Reign of error, 102-103 entre otras), las diferencias tanto en los resultados académicos como en los test de las evaluaciones externas en Estados Unidos se deben en un 60-75\% a las diferencias en el contexto social y familiar del alumnado.

${ }^{64}$ Gabriel González Bueno y Armando Bello, La infancia en España 2014. El valor social de los niños; hacia un Pacto Social de la Infancia (Madrid: UNICEF Comité Español, 2014): Accesible en http://www. unicef.es/sites/www.unicef.es/files/infancia-espana/unicef_informe_la_infancia_en_espana_2014.pdf. Sara Ayllon Gatnau, Infancia, pobreza y crisis económica (Barcelona: Obra Social La Caixa, 2014). http:// obrasocial.lacaixa.es/deployedfiles/obrasocial/Estaticos/pdf/Estudios_sociales/vol40_es.pdf. Consultados el 9 de junio de 2015.
} 


\section{Nota sobre el autor:}

Antonio Viñao Frago es Doctor en Derecho y Profesor Emérito de Teoría e Historia de la Educación de la Universidad de Murcia. Ha sido miembro del Comité Ejecutivo de la International Standing Conference for the History of Education (ISCHE) (1996-2000) y presidente de la Sociedad Española de Historia de la Educación (2001-2005), así como director del Centro de Estudios sobre la Memoria Educativa (CEME) de la Universidad de Murcia (2009-2013). Sus campos de investigación prioritarios son la historia de la alfabetización y de la cultura escrita, de la escolarización y de la enseñanza secundaria, así como la historia del currículum (espacios y tiempos escolares, disciplinas, libros de texto), de la memoria escolar (egodocumentos, imágenes) y de la relación entre las culturas escolares y las reformas educativas. De entre sus libros publicados destacan los siguientes: Política y educación en los orígenes de la España contemporánea. Examen especial de sus relaciones en la enseñanza secundaria (1982), Innovación pedagógica y racionalidad científica. La escuela graduada pública en España (1898-1936) (1990), Tiempos escolares, tiempos sociales. La distribución del tiempo y del trabajo en la enseñanza primaria en España (1838-1936) (1998), Leer y escribir. Historia de dos prácticas culturales (1999), Sistemas educativos, culturas escolares y reformas: continuidades y cambios (2002), Escuela para todos. Educación y modernidad en la España del siglo XX (2004) y Religión en las aulas: una materia controvertida (2014). 